\title{
Mössbauer spectroscopic characterization of ferrites as adsorbents for reactive adsorption desulfurization
}

\author{
Xiao Chen a, Kaixin Zhu b,c, M. A. Ahmed d, Junhu Wang b,*, Changhai Liang a,\# \\ a Laboratory of Advanced Materials and Catalytic Engineering, School of Chemical Engineering, Dalian University of Technology, Dalian 116012, Liaoning, \\ China \\ b Mössbauer Effect Data Center, Dalian Institute of Chemical Physics, Chinese Academy of Sciences, Dalian 116023, Liaoning, China \\ c University of Chinese Academy of Sciences, Beijing 100049, China \\ d Physics Department, Faculty of Science, Al Azhar University, Cairo, Egypt
}

\section{A R T I C L E I N F O}

Article history:

Received 13 January 2016

Accepted 21 February 2016

Published 5 May 2016

Keywords:

Ferrite

Adsorptive desulfurization

Mössbauer spectroscopy

Regeneration

\begin{abstract}
A B S T R A C T
Sulfur in transportation fuels is a major source of air pollution. New strategies for the desulfurization of fuels have been explored to meet the urgent need to produce cleaner gasoline. Adsorptive desulfurization (ADS) is one of the most promising complementary and alternative methods. Herein, nanocrystalline ferrite adsorbents were synthesized from metal nitrates and urea using a microwave assisted combustion method. A series of ADS experiments were performed using a fixed-bed reactor to evaluate the ADS reactivity over the ferrites, which was found to have the order $\mathrm{MgFe}_{2} \mathrm{O}_{4}>\mathrm{NiFe}_{2} \mathrm{O}_{4}>\mathrm{CuZnFe}_{2} \mathrm{O}_{4}>\mathrm{ZnFe}_{2} \mathrm{O}_{4}>\mathrm{CoFe}_{2} \mathrm{O}_{4}$. This effect is explained by the fact that the low degree of alloying of $\mathrm{Mg}$ - $\mathrm{Fe}$ and the doped $\mathrm{Mg}$ increased the interaction between Fe and $\mathrm{S}$ compounds, leading to a significant improvement in the desulfurization capability of the adsorbent. Additionally, Mg can dramatically promote the decomposition of thiophene. X-ray diffraction and Mössbauer spectroscopy were used to characterize the fresh, regenerated, and sulfided adsorbents. Although the ferrite adsorbents were partially sulfided to bimetallic sulfides during the adsorption process, they were successfully regenerated after calcining at $500{ }^{\circ} \mathrm{C}$ in air.
\end{abstract}

(C) 2016, Dalian Institute of Chemical Physics, Chinese Academy of Sciences. Published by Elsevier B.V. All rights reserved.

\section{Introduction}

Sulfur in transportation fuels such as diesel, gasoline, and jet fuel remains a major source of air pollution [1]. More stringent environmental regulations for the oil refining industry have been enacted worldwide, and the Euro $\mathrm{V}$ emission standards require the sulfur content in gasoline to be less than $10 \mathrm{ppm}$. However, it is difficult to reduce the sulfur of liquid fuels to a very low level with conventional hydro desulfurization methods without a decrease in octane number. Therefore, new strategies for desulfurization have been explored to meet the urgent need to produce cleaner gasoline [2].

Adsorptive desulfurization (ADS) is one of the most promising complementary and alternative desulfurization techniques. Reactive adsorption refers to processes using metal-based adsorbents to capture sulfur to form metal sulfides in the presence of hydrogen [3]. The sulfur atom is retained on the adsorbent, while the hydrocarbon portion of the fuel molecule is released back into the process stream. This process can achieve ultra-deep desulfurization with low octane number

\footnotetext{
*Corresponding author. Tel: +86-411-84379159; Fax: +86-411-84685940; E-mail: wangjh@dicp.ac.cn

\#Corresponding author. Tel: +86-411-84986353; Fax: +86-411-84986353; E-mail: changhai@dlut.edu.cn

This work was supported by the National Natural Science Foundation of China (21373038, 21403026, and 21476232), the China Postdoctoral Science Foundation (2015T80255 and 2014M551068), and the China-Egypt Scientific-Technologic Exchange Project (21311140474). 
loss. During the past decade, several reports have been published on fuel desulfurization by reactive adsorption [4-6]. The Conoco Phillips Petroleum Company developed what is known as a S-Zorb process using $\mathrm{Ni} / \mathrm{ZnO}$ as an effective reactive adsorbent for the production of low sulfur gasoline [4,5]. In this adsorbent, Ni functions as a hydro desulfurization site, while $\mathrm{ZnO}$ takes up the produced $\mathrm{H}_{2} \mathrm{~S}$ and is simultaneously converted into $\mathrm{ZnS}$. Gao's group [6] studied the use of $\mathrm{Ni} / \mathrm{ZnO}-\mathrm{SiO}_{2}-$ $\mathrm{Al}_{2} \mathrm{O}_{3}$ as an adsorbent for the ADS of fluid catalytic cracking (FCC) gasoline in a fixed-fluidized bed reactor at low pressures in the presence of hydrogen. Their results indicated that high temperature, high pressure, high hydrogen-to-oil molar ratio, and low weight hourly space velocity (LHSV) are favorable for improving the desulfurization ability of the adsorbent but are not conducive to maintaining the octane number of FCC gasoline.

Additionally, kinetic experiments in a thermobalance and performance tests in different types of reactors have shown that ferrites can be used as regenerable adsorbents for hot coal gas desulfurization in integrated gasification combined cycle (IGCC) technologies for clean and efficient power generation [7]. The $\mathrm{H}_{2} \mathrm{~S}$ concentration in the outlet gas from a fixed-bed reactor can be as low as a few ppm and the ferrite adsorbent conversion at breakthrough may be above $70 \%$, indicating a high adsorbent reactivity for the sulfidation process $[8,9]$. However, these features are frequently associated with structural changes occurring both in the fresh or regenerated and the sulfided adsorbents, and, unfortunately, these changes are not easy to detect with the usual characterization techniques.

In this study, nanocrystalline ferrite adsorbents were synthesized from stoichiometric metal nitrate and urea mixtures using a microwave assisted combustion method. To evaluate the ADS reactivity over the ferrites, a series of ADS experiments with a model gasoline feedstock ( $n$-heptane containing thiophene) were performed using a fixed-bed reactor. The structural changes occurring in the ferrites during calcination at high temperature or regeneration in oxidizing atmosphere and the metallic sulfides formed during the sulfidation process were investigated in detail by powder X-ray diffraction (XRD) and ${ }^{57} \mathrm{Fe}$ Mössbauer spectroscopy.

\section{Experimental}

\subsection{Preparation of $\mathrm{AFe}_{2} \mathrm{O}_{4}$ adsorbents}

Nanocrystalline ferrites $\mathrm{AFe}_{2} \mathrm{O}_{4}(\mathrm{~A}=\mathrm{Mg}, \mathrm{Co}, \mathrm{Ni}, \mathrm{Zn}$, and $\mathrm{CuZn}$ ) were prepared by the exothermic reaction of mixtures of metallic nitrates (metallic A and $\mathrm{Fe}$ ) and urea $\left(\mathrm{CO}\left(\mathrm{NH}_{2}\right)_{2}\right.$ ) (as reducing agent) $[10,11]$. Stoichiometric ratios of metallic nitrate $\left(\mathrm{A}\left(\mathrm{NO}_{3}\right)_{2} \cdot n \mathrm{H}_{2} \mathrm{O}\right)$, ferric nitrate $\left(\mathrm{Fe}\left(\mathrm{NO}_{3}\right)_{3} \cdot 9 \mathrm{H}_{2} \mathrm{O}\right)$, and urea were dissolved in a small amount of doubly distilled water. The molar ratios in the mixture were $1.7(\mathrm{U}): 1(\mathrm{M}): 16.65(\mathrm{~W})$, where $\mathrm{U}, \mathrm{M}$, and $\mathrm{W}$ denote the molar ratios of urea, metal nitrates, and water, respectively. The vessel containing the solution was placed in a microwave oven that was then operated at a maximum power of $800 \mathrm{~W}$ for $20 \mathrm{~min}$. The solution boiled and underwent dehydration followed by decomposition with the evo- lution of large amounts of gas. After the solution reached the point of spontaneous combustion, it instantly became a solid powder accompanied by the release of large amounts of heat and vapor.

\subsection{Characterization of adsorbents}

XRD analyses of the samples were carried out using a Rigaku D/Max-RB diffractometer with a $\mathrm{Cu} K_{\alpha}$ monochromatized radiation source operated at $40 \mathrm{kV}$ and $100 \mathrm{~mA}$. The XRD patterns were compared with the calculated patterns obtained from the Inorganic Crystal Structure Database (ICSD) using Jade 6.0 software. The crystallite sizes of the prepared and annealed samples were estimated using the Scherrer equation.

${ }^{57} \mathrm{Fe}$ Mössbauer spectra were recorded on a Topologic $500 \mathrm{~A}$ spectrometer with a proportional counter at room temperature. ${ }^{57} \mathrm{Co}(\mathrm{Rh})$ moving in constant acceleration mode was used as the radioactive source. All spectral analyses were conducted assuming a Lorentzian line shape for computer fitting. The Doppler velocity of the spectrometer was calibrated with respect to $\alpha$-Fe foil.

\subsection{Evaluation of ADS performance of ferrites}

The adsorption experiments were performed in a fixed-bed reactor at $500{ }^{\circ} \mathrm{C}$ under the following operating conditions: 0.3 g catalyst diluted to $3 \mathrm{~mL}$ with $\mathrm{SiO}_{2}, \mathrm{H}_{2}$ partial pressure of 1.0 MPa, LHSV of $2 \mathrm{~h}^{-1}$, and $\mathrm{H}_{2}$ /oil of 600 . The model gasoline feedstock was $n$-heptane containing thiophene, with a total sulfur concentration of $3000 \mathrm{mg} / \mathrm{L}$. All of the sulfur contents reported in this work were determined by gas chromatography (GC) analysis. The sulfur removal was expressed as the equation [12]: Sulfur removal $=\left(1-C_{t} / C_{0}\right) \times 100 \%$, where $C_{0}$ is the sulfur concentration in the feedstock $(\mathrm{mg} / \mathrm{L})$ and $C_{t}$ is the transient effluent sulfur concentration (mg/L) at any time $t$ (min). Additionally, a regeneration experiment for the ferrite adsorbents was conducted at $500{ }^{\circ} \mathrm{C}$ in air and was considered to be complete when $\mathrm{SO}_{2}$ was undetectable in the outlet gas.

\section{Results and discussion}

Figure 1 shows the XRD patterns of representative samples of ferrites synthesized by the microwave combustion method using various metallic nitrates. The pattern of the $\mathrm{MgFe}_{2} \mathrm{O}_{4}$ sample indicated a low crystallinity, with two broad peaks (around $2 \theta=35^{\circ}$ and $63^{\circ}$ ) corresponding to the position of the two main peaks of spinel ferrite. The diffraction peaks of the Co, $\mathrm{Ni}$, and $\mathrm{Zn}$ ferrite samples were perfectly indexed to a single phase with cubic spinel structure of space group $\mathrm{Fd}-3 \mathrm{~m}$ (standard JCPDS Card Nos. 22-1086 of cubic $\mathrm{CoFe}_{2} \mathrm{O}_{4}, 10-0325$ of cubic trevorite $\mathrm{NiFe}_{2} \mathrm{O}_{4}$, and 22-1012 of cubic $\mathrm{ZnFe}_{2} \mathrm{O}_{4}$ ), and no secondary phases were detected in the XRD patterns. This confirmed the phase purity of the final products. The broadening of the peaks for these samples indicates the fine particle nature of the ferrite powder [13]. Additionally, all the peaks of the CuZ$n \mathrm{Fe}_{2} \mathrm{O}_{4}$ sample matched well with those of standard JCPDS Card No. 22-1012 for the cubic $\mathrm{ZnFe}_{2} \mathrm{O}_{4}$ phase. The positions of the 


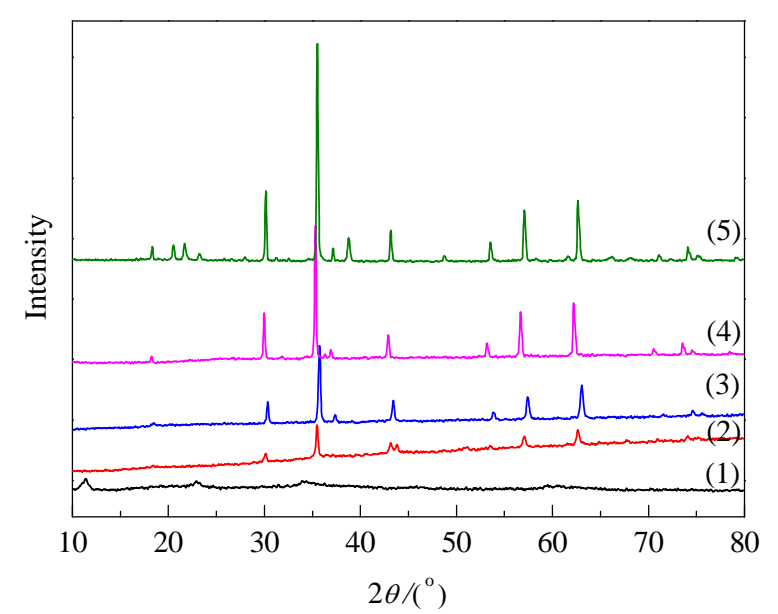

Fig. 1. Powder $\mathrm{XRD}$ patterns of $\mathrm{AFe}_{2} \mathrm{O}_{4}$ ferrites obtained by the microwave combustion method. (1) $\mathrm{MgFe}_{2} \mathrm{O}_{4}$; (2) $\mathrm{CoFe}_{2} \mathrm{O}_{4}$; (3) $\mathrm{NiFe}_{2} \mathrm{O}_{4}$; (4) $\mathrm{ZnFe}_{2} \mathrm{O}_{4}$; (5) $\mathrm{CuZnFe}_{2} \mathrm{O}_{4}$.

XRD peaks were shifted to higher $2 \theta$ owing to the doping of $\mathrm{Cu}$ in the zinc ferrite. This shift can be explained by the fact that the doping cation $\mathrm{Cu}^{2+}(0.073 \mathrm{~nm})$ has a smaller ionic radius than that of $\mathrm{Zn}^{2+}(0.083 \mathrm{~nm})$ and by a possible redistribution of $\mathrm{Zn}^{2+}$ and $\mathrm{Fe}^{3+}$ ions caused by $\mathrm{Cu}^{2+}$ ions in the tetrahedral/octahedral ionic sites [11]. Furthermore, using the Scherrer equation, the particle size of the ferrites was calculated 5.0, 27.6, 44.6, 72.3, and $92.0 \mathrm{~nm}$ for the $\mathrm{MgFe}_{2} \mathrm{O}_{4}, \mathrm{CoFe}_{2} \mathrm{O}_{4}, \mathrm{NiFe}_{2} \mathrm{O}_{4}$, $\mathrm{ZnFe}_{2} \mathrm{O}_{4}$, and $\mathrm{CuZnFe}_{2} \mathrm{O}_{4}$ samples, respectively. A small particle size may be expected to reduce the diffusion path and promote the adsorption desulfurization performance of the ferrites to some extent. The doping of $\mathrm{Cu}$ in the zinc ferrite resulted in a measurable progressive increase in the degree of crystallinity of the produced cubic phase. The formation of $\mathrm{Cu}$-doped zinc ferrites is more endothermic than the formation of pure Zn-ferrite. When $\mathrm{Cu}$ was introduced into the system, less heat would have been liberated, thereby increasing the molecular concentration of $\mathrm{Cu}$ at the crystal surface and degree of crystallinity of the product.

The desulfurization reactivity over the $\mathrm{AFe}_{2} \mathrm{O}_{4}$ adsorbents was compared under the reaction conditions with model gasoline ( $n$-heptane containing thiophene to a total sulfur concentration of $3000 \mathrm{mg} / \mathrm{L}$ ). The breakthrough curves of sulfur over the adsorbents are shown in Fig. 2. Generally, there are two basic components in a reaction ADS adsorbent: the reactive part $(\mathrm{Ni}, \mathrm{Cu}, \mathrm{Co}, \mathrm{Pt}$, and $\mathrm{Pd})$, which has a relatively high affinity for sulfur compounds, and the adsorptive part $\left(\mathrm{ZnO}, \mathrm{MnO}_{2}, \mathrm{FeO}\right.$, and $\mathrm{CaO}$ ) that accepts the sulfur and regenerates the reactive part [14]. However, there have only been a few studies of ferrites as ADS adsorbents until now. In our study, the ferrites may have been partially reduced in the $\mathrm{H}_{2}$ atmosphere during the ADS process, forming metal or alloy and metallic oxide composites to serve as the adsorptive and reactive part, respectively. In a blank experiment, the sulfur removal reached $27 \%$, which indicated that the thiophene was partially thermally-decomposed at the chosen reaction temperature (500 ${ }^{\circ} \mathrm{C}$ ). The $\mathrm{MgFe}_{2} \mathrm{O}_{4}$ adsorbent initially gave a high sulfur removal of $95 \%$, but was partially deactivated to $75 \%$ by $40 \mathrm{~h}$, while the
$\mathrm{ZnFe}_{2} \mathrm{O}_{4}$ adsorbent also exhibited a high initial sulfur removal of $100 \%$ but was deactivated by $50 \%$ within the same period. This indicated that structural change of the ferrites and the formation of iron sulfides occurred during the desulfurization process.

The results in Fig. 2 show that the desulfurization capability of the ferrite adsorbents during the $40 \mathrm{~h}$ continuous ADS process had the following sequence: $\mathrm{MgFe}_{2} \mathrm{O}_{4}>\mathrm{NiFe}_{2} \mathrm{O}_{4}>\mathrm{CuZ}$ $\mathrm{nFe}_{2} \mathrm{O}_{4}>\mathrm{ZnFe}_{2} \mathrm{O}_{4}>\mathrm{CoFe}_{2} \mathrm{O}_{4}$, which may have been caused by the different types of ferrite with probable site migration and/or change in oxidation state. $\mathrm{MgFe}_{2} \mathrm{O}_{4}$ exhibited the highest ADS properties, which may have been because its spinel structure was not destroyed in the reducing atmosphere used and because the doped Mg increased the interaction between Fe and S compounds, leading to a significant improvement in the desulfurization capability of the adsorbent. Additionally, basic/acid sites provided by adsorbents may promote the decomposition of thiophene $[15,16]$. Mg is a generally basic element which can dramatically promote the decomposition of thiophene, which may also have given $\mathrm{MgFe}_{2} \mathrm{O}_{4}$ the best desulfurization performance. Furthermore, doping with $\mathrm{Cu}$ can substantially increase the overall sulfidation rate of zinc ferrite, because $\mathrm{Cu}$ increases the amount of reactive part and thereby the desulphurization performance. This result is similar to those observed for $\mathrm{Cu}$-doped zinc ferrites used as regenerable adsorbents for hot coal gas desulfurization [9].

To understand the relationship between the structures of the ferrites and their desulfurization properties in depth, a detailed characterization of the ferrites was carried out. The structure of the ferrites was found to have changed significantly after the ADS experiments, as shown in Fig. 3. These structural changes were observed through the formation of different types of metallic sulfides during the sulfidation process. Typical diffraction peaks at $2 \theta=29.9^{\circ}, 33.8^{\circ}, 43.6^{\circ}$, and $53.1^{\circ}$ corresponding to those of $\mathrm{Fe}_{1-x} \mathrm{~S}$ (JCPDS No. 29-0725) were detected in the XRD pattern of the $\mathrm{MgFe}_{2} \mathrm{O}_{4}$ sample. Trace amounts of FeS were also found. The crystalline phases of the $\mathrm{AFe}_{2} \mathrm{O}_{4}(\mathrm{~A}=$

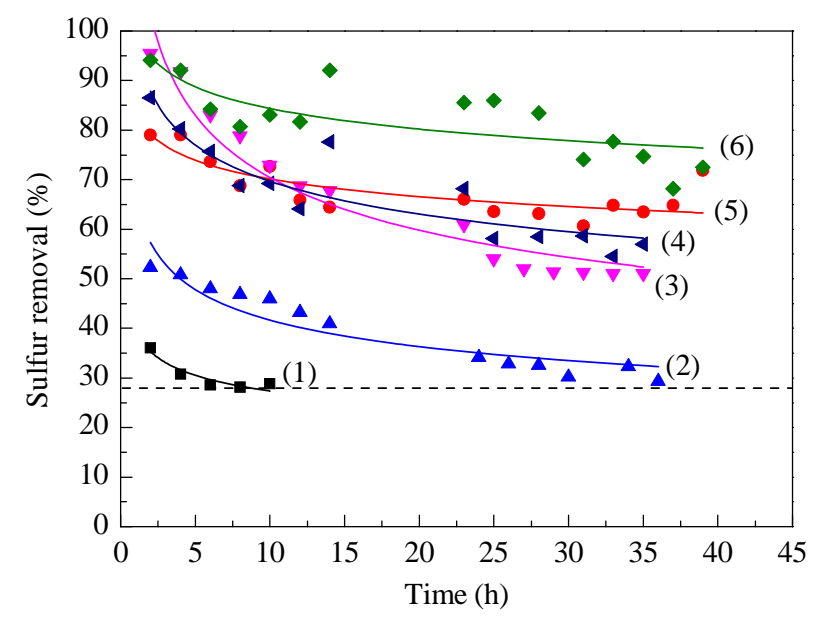

Fig. 2. Breakthrough curves for adsorptive desulfurization of model gasoline on $\mathrm{AFe}_{2} \mathrm{O}_{4}$ adsorbents at $500^{\circ} \mathrm{C}, \mathrm{H}_{2}$ partial pressure $=1.0 \mathrm{MPa}$, LHSV = $2 \mathrm{~h}^{-1}$, and $\mathrm{H}_{2}$ /oil = 600. (1) Blank; (2) $\mathrm{CoFe}_{2} \mathrm{O}_{4}$; (3) $\mathrm{ZnFe}_{2} \mathrm{O}_{4}$; (4) $\mathrm{CuZnFe}_{2} \mathrm{O}_{4}$; (5) $\mathrm{NiFe}_{2} \mathrm{O}_{4}$; (6) $\mathrm{MgFe}_{2} \mathrm{O}_{4}$. 


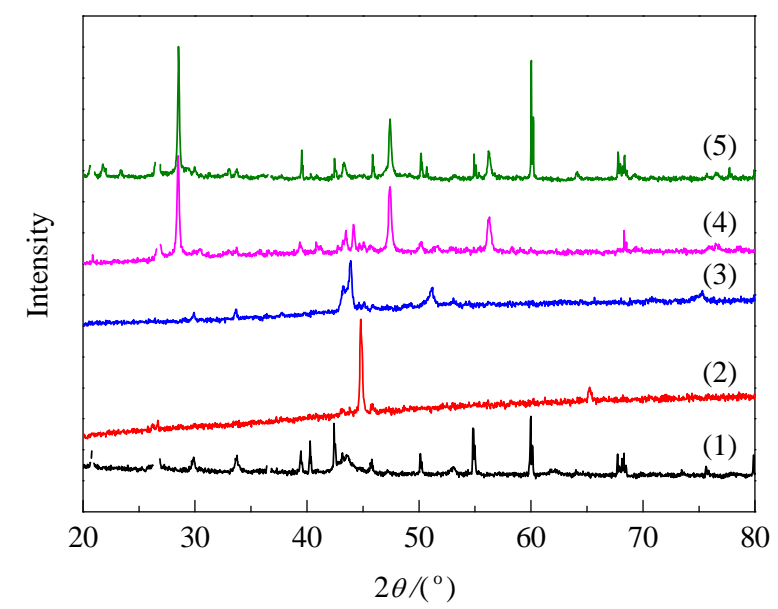

Fig. 3. Powder $\mathrm{XRD}$ patterns of $\mathrm{AFe}_{2} \mathrm{O}_{4}$ ferrite adsorbents after $\mathrm{ADS}$ experiments. (1) $\mathrm{MgFe}_{2} \mathrm{O}_{4}$; (2) $\mathrm{CoFe}_{2} \mathrm{O}_{4}$; (3) $\mathrm{NiFe}_{2} \mathrm{O}_{4}$; (4) $\mathrm{ZnFe}_{2} \mathrm{O}_{4}$; (5) $\mathrm{CuZnFe}_{2} \mathrm{O}_{4}$.

$\mathrm{Ni}, \mathrm{Zn}$, and CuZn) adsorbents were identified by comparison with standard iron sulfide JCPDS files (hexagonal FeS, No. 37-0477 and cubic FeS, No. 23-1123), which confirmed that the ferrite adsorbents had been sulfided during the ADS process. Especially, the presence of $\mathrm{ZnS}$ phase was found in the pattern of the $\mathrm{ZnFe}_{2} \mathrm{O}_{4}$ sample, which means that $\mathrm{ZnO}$ in the $\mathrm{ZnFe}_{2} \mathrm{O}_{4}$ system acted as a sulfur acceptor via diffused $\mathrm{H}_{2} \mathrm{~S}$ from the thiophene [17]. Additionally, crystalline $\mathrm{Co}_{3} \mathrm{Fe}_{7}$ (JCPD No. 48-1816) or CoFe (JCPD No. 44-1433) phase was detected in the $\mathrm{CoFe}_{2} \mathrm{O}_{4}$ sample, and $\mathrm{Fe}_{0.64} \mathrm{Ni} 0.36$ phase (JCPD No. 47-1405) was detected in the $\mathrm{NiFe}_{2} \mathrm{O}_{4}$ sample. The formation of Fe-base alloy may have protected the metallic phase from agglomeration during the subsequent reduction treatment and desulfurization process [12]. However, the formation of Fe-base alloy may weaken the $\mathrm{Fe}-\mathrm{S}$ bond and adversely affect reactive ADS. Combined with the structural changes and the ADS properties, it can be speculated that the formation of Fe-base alloy works against desulfurization, suppressing the metal to metallic sulfide transformation.

In spinel ferrites $\mathrm{AFe}_{2} \mathrm{O}_{4}\left(\mathrm{~A}=\mathrm{Mg}^{2+}, \mathrm{Co}^{2+}, \mathrm{Ni}^{2+}, \mathrm{Cu}^{2+}, \mathrm{Zn}^{2+}\right.$, etc.), there are twice as many octahedral $\mathrm{B}$ cationic sites as tetrahedral cationic A sites. In normal spinel, A divalent ions occupy the tetrahedral sites and only $\mathrm{Fe}^{3+}$ ions occupy the octahedral sites. In contrast, in the inverse spinel, A divalent ions occupy the octahedral sites and $\mathrm{Fe}^{3+}$ ions are equally distributed in octahedral and tetrahedral sites [18]. ${ }^{57} \mathrm{Fe}$ Mössbauer spectroscopy is a tool for clarifying the chemical state and relative amount of iron species in a material, which can assist in understanding the structural changes of ferrites during the ADS process.

Room temperature Mössbauer spectra of representative ferrite samples are shown in Fig. 4. The spectral parameters such as isomer shift (IS, $\delta$ ), quadrupole splitting (QS, $\Delta$ ) and hyperfine field $(H)$ were computed and are summarized in Table 1. As shown in Fig. 4, the spectrum of fresh $\mathrm{MgFe}_{2} \mathrm{O}_{4}$ was fitted well by two doublets with IS $=0.16 \mathrm{~mm} / \mathrm{s}, \mathrm{QS}=0.63$ $\mathrm{mm} / \mathrm{s}$ and IS $=0.34 \mathrm{~mm} / \mathrm{s}, \mathrm{QS}=0.66 \mathrm{~mm} / \mathrm{s}$, which can be ascribed to tetrahedrally and octahedrally oxygen-coordinated

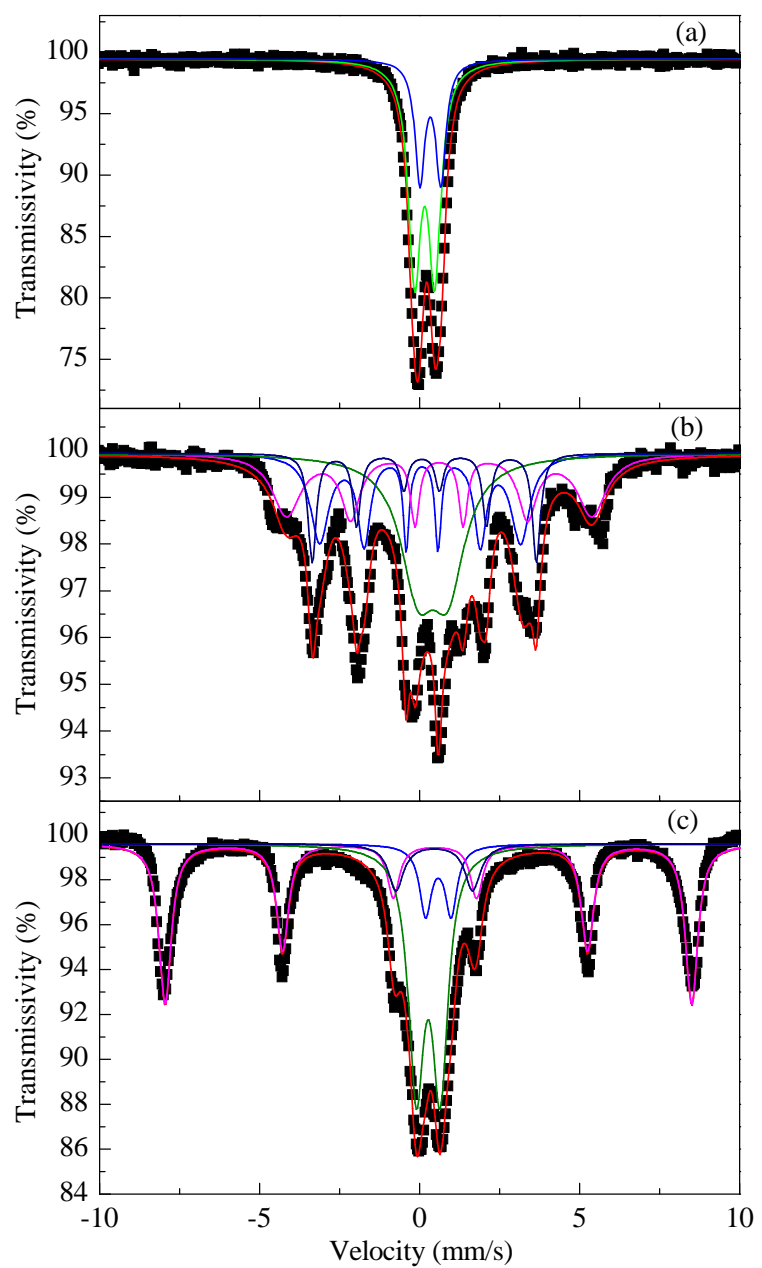

Fig. 4. ${ }^{57} \mathrm{Fe}$ Mössbauer spectra of (a) fresh, (b) spent, and (c) regenerated $\mathrm{MgFe}_{2} \mathrm{O}_{4}$ adsorbent.

$\mathrm{Fe}^{3+}$ ions in $\left(\mathrm{Mg}^{2+}{ }_{1-x} \mathrm{Fe}^{3+} x\right)_{\mathrm{A}}\left[\mathrm{Mg}^{2+}{ }_{x} \mathrm{Fe}^{3+}{ }_{2-x}\right]_{\mathrm{B}} \mathrm{O}^{2-}{ }_{4}$ magnesium ferrite, where round and square brackets denote tetrahedral (A) and octahedral $[\mathrm{B}]$ coordination sites, respectively, and where $x$ represents the degree of inversion [19]. Based on the Mössbauer parameters of the doublets for $\mathrm{MgFe}_{2} \mathrm{O}_{4}$, it was concluded that spinel $\mathrm{MgFe}_{2} \mathrm{O}_{4}$ had been successfully synthesized by

Table 1

${ }^{57} \mathrm{Fe}$ Mössbauer parameters of $\mathrm{MgFe}_{2} \mathrm{O}_{4}$ samples.

\begin{tabular}{|c|c|c|c|c|c|c|}
\hline Sample & $\begin{array}{c}A \\
(\%) \\
\end{array}$ & $\begin{array}{c}\delta^{\mathrm{a}} \\
(\mathrm{mm} / \mathrm{s}) \\
\end{array}$ & $\begin{array}{c}H \\
(\mathrm{~T}) \\
\end{array}$ & $\begin{array}{c}\Delta \\
(\mathrm{mm} / \mathrm{s}) \\
\end{array}$ & $\begin{array}{c}2 \Gamma \\
(\mathrm{mm} / \mathrm{s}) \\
\end{array}$ & Site $^{b}$ \\
\hline \multirow[t]{2}{*}{ Fresh } & 68.6 & 0.16 & - & 0.63 & 0.47 & A-site in $\mathrm{MgFe}_{2} \mathrm{O}_{4}$ \\
\hline & 31.4 & 0.34 & - & 0.66 & 0.37 & B-site in $\mathrm{MgFe}_{2} \mathrm{O}_{4}$ \\
\hline \multirow{4}{*}{ Spent } & 25.9 & 0.05 & 19.5 & -0.07 & 0.22 & $\mathrm{C}$-site in $\mathrm{Fe}_{1-x} \mathrm{~S}$ \\
\hline & 27.8 & 0.61 & 29.7 & 0.00 & 0.32 & A-site in $\mathrm{Fe}_{1-x} \mathrm{~S}$ \\
\hline & 32.6 & 0.41 & - & 0.94 & 1.29 & $\mathrm{MgFeS}$ \\
\hline & 13.6 & 0.11 & 21.8 & 0.08 & 0.30 & B-site in $\mathrm{Fe}_{1-x} \mathrm{~S}$ \\
\hline \multirow[t]{4}{*}{ Regenerated } & 9.2 & 0.58 & - & 0.80 & 0.46 & A-site in $\mathrm{MgFe}_{2} \mathrm{O}_{4}$ \\
\hline & 43.0 & 0.38 & 51.0 & -0.21 & 0.46 & $\alpha-\mathrm{Fe}_{2} \mathrm{O}_{3}$ \\
\hline & 39.9 & 0.27 & - & 0.75 & 0.58 & $\mathrm{~B}$-site in $\mathrm{MgFe}_{2} \mathrm{O}_{4}$ \\
\hline & 7.9 & 0.46 & - & 2.40 & 0.58 & $\begin{array}{c}\mathrm{MgFe}_{2} \mathrm{O}_{4} \text { with } \\
\text { oxygen vacancies }\end{array}$ \\
\hline
\end{tabular}

a Relative to $\alpha$-Fe at room temperature.

${ }^{\mathrm{b}}$ Site identification considered to be the most probable case. 
the microwave assisted combustion method. The structural change of the $\mathrm{MgFe}_{2} \mathrm{O}_{4}$ during the ADS process was determined from measurements of the chemical state of Fe in the spent adsorbent, as shown in Fig. 4(b) and Table 1. The Mössbauer spectrum could be fitted with one doublet and three sextets. The doublet with IS $=0.41 \mathrm{~mm} / \mathrm{s}$ and $\mathrm{QS}=0.94 \mathrm{~mm} / \mathrm{s}$ associated with the MgFe bimetallic sulfide (MgFeS) accounted for $32.6 \%$ of the total spectral area. The sextets with IS $=0.61$ $\mathrm{mm} / \mathrm{s}, \mathrm{QS}=0.00 \mathrm{~mm} / \mathrm{s}$, and $H=29.7 \mathrm{~T}$ could be ascribed to A sites in $\mathrm{Fe}_{1-x} \mathrm{~S}$ pyrrhotite. The other two sextets, which had IS = $0.11 \mathrm{~mm} / \mathrm{s}, \mathrm{QS}=0.08 \mathrm{~mm} / \mathrm{s}$, and $H=21.8 \mathrm{~T}$ and $\mathrm{IS}=0.05$ $\mathrm{mm} / \mathrm{s}, \mathrm{QS}=-0.07 \mathrm{~mm} / \mathrm{s}$, and $H=19.5 \mathrm{~T}$ were attributed to Bsites and $\mathrm{C}$-sites in $\mathrm{Fe}_{1-x} \mathrm{~S}$ pyrrhotite, respectively. The A-, B-, and $\mathrm{C}$-sites in $\mathrm{Fe}_{1-\mathrm{x}} \mathrm{S}$ were assigned according to the hyperfine field distribution. The high ratio of $\mathrm{Fe}_{1-x} \mathrm{~S}$ phase in the spent $\mathrm{MgFe}_{2} \mathrm{O}_{4}$ sample (ca. $67.4 \%$ of the total spectral area) was not sulfurized completely, which explained why the $\mathrm{MgFe}_{2} \mathrm{O}_{4}$ maintained a high sulfur removal activity after $40 \mathrm{~h}$ continuous ADS. Combined with the XRD data for spent $\mathrm{MgFe}_{2} \mathrm{O}_{4}$, it can be speculated that the $\mathrm{MgFe}_{2} \mathrm{O}_{4}$ was decomposed and reduced by $\mathrm{H}_{2}$ during the ADS process, leading to its structural distortion. The sulfur content on the surface of the $\mathrm{MgFe}_{2} \mathrm{O}_{4}$ increased significantly with elapsed ADS time, which led to it taking on the general formula of ferrous sulfide, $\mathrm{Fe}_{1-x} \mathrm{~S}$. This result is similar to the thermodynamic behavior and phase transformation of transition metal-sulfur systems, especially in the Fe-S system [20].

For the ADS process, it is crucial to regenerate the adsorbent. In this work, the regeneration of sulfurized $\mathrm{MgFe}_{2} \mathrm{O}_{4}$ was conducted at $500{ }^{\circ} \mathrm{C}$ in air and was considered to be complete when $\mathrm{SO}_{2}$ was undetectable in the outlet gas. As shown in Fig. 4 (c), the Mössbauer spectrum of regenerated $\mathrm{MgFe}_{2} \mathrm{O}_{4}$ could be fitted with a sextet and three doublets. The sextet associated with $\alpha-\mathrm{Fe}_{2} \mathrm{O}_{3}$ accounted for $43.0 \%$ of the total spectral area. The doublet having Mössbauer parameters of IS $=0.46 \mathrm{~mm} / \mathrm{s}$ and $\mathrm{QS}=2.40 \mathrm{~mm} / \mathrm{s}$ accounted for about $7.9 \%$ and was attributed to $\mathrm{MgFe}_{2} \mathrm{O}_{4}$ with oxygen vacancies, which means that the sulfurized $\mathrm{MgFe}_{2} \mathrm{O}_{4}$ was re-oxidized after treatment at 500 ${ }^{\circ} \mathrm{C}$ for $3 \mathrm{~h}$ in air. Moreover, about $50 \%$ of the $\mathrm{MgFe}_{2} \mathrm{O}_{4}$ was regenerated completely. As shown in Table 1, the two doublets with IS $=0.27 \mathrm{~mm} / \mathrm{s}, \mathrm{QS}=0.75 \mathrm{~mm} / \mathrm{s}$ and $\mathrm{IS}=0.58 \mathrm{~mm} / \mathrm{s}, \mathrm{QS}=$ $0.80 \mathrm{~mm} / \mathrm{s}$ were assigned to the A-sites and B-sites in $\mathrm{MgFe}_{2} \mathrm{O}_{4}$, respectively, and were similar to those detected in fresh $\mathrm{MgFe}_{2} \mathrm{O}_{4}$. Therefore, the regeneration process was effective in eliminating all traces of iron sulfides in the $\mathrm{MgFe}_{2} \mathrm{O}_{4}$ adsorbent.

The Mössbauer spectra and parameters of fresh, spent, and regenerated $\mathrm{NiFe}_{2} \mathrm{O}_{4}$ adsorbent are shown in Fig. 5 and Table 2, respectively. The spectrum of $\mathrm{NiFe}_{2} \mathrm{O}_{4}$ consisted of two clearly split Zeeman sextets. The isomer shifts of the sextets were in the range of $0.27-0.37 \mathrm{~mm} / \mathrm{s}$, which is typical of that for $\mathrm{Fe}^{3+}$ ions. Bulk $\mathrm{NiFe}_{2} \mathrm{O}_{4}$ has an inverse spinel structure in which $\mathrm{Ni}^{2+}$ occupies $\mathrm{B}$-sites totally while the $\mathrm{Fe}^{3+}$ ions are distributed between $\mathrm{A}$ - and $\mathrm{B}$-sites as $\left(\mathrm{Fe}^{3+}\right)_{\mathrm{A}}\left[\mathrm{Fe}^{3+}, \mathrm{Ni}^{2+}\right]_{\mathrm{B}} \mathrm{O}^{2-}[21]$. As shown in Table 2, the fraction of iron ions in $(A)$ and $[B]$ sites in the $\mathrm{NiFe}_{2} \mathrm{O}_{4}$ sample were $59 \%$ and $39 \%$, respectively, which indicated that spinel $\mathrm{NiFe}_{2} \mathrm{O}_{4}$ had been successfully synthesized by the microwave assisted combustion method.

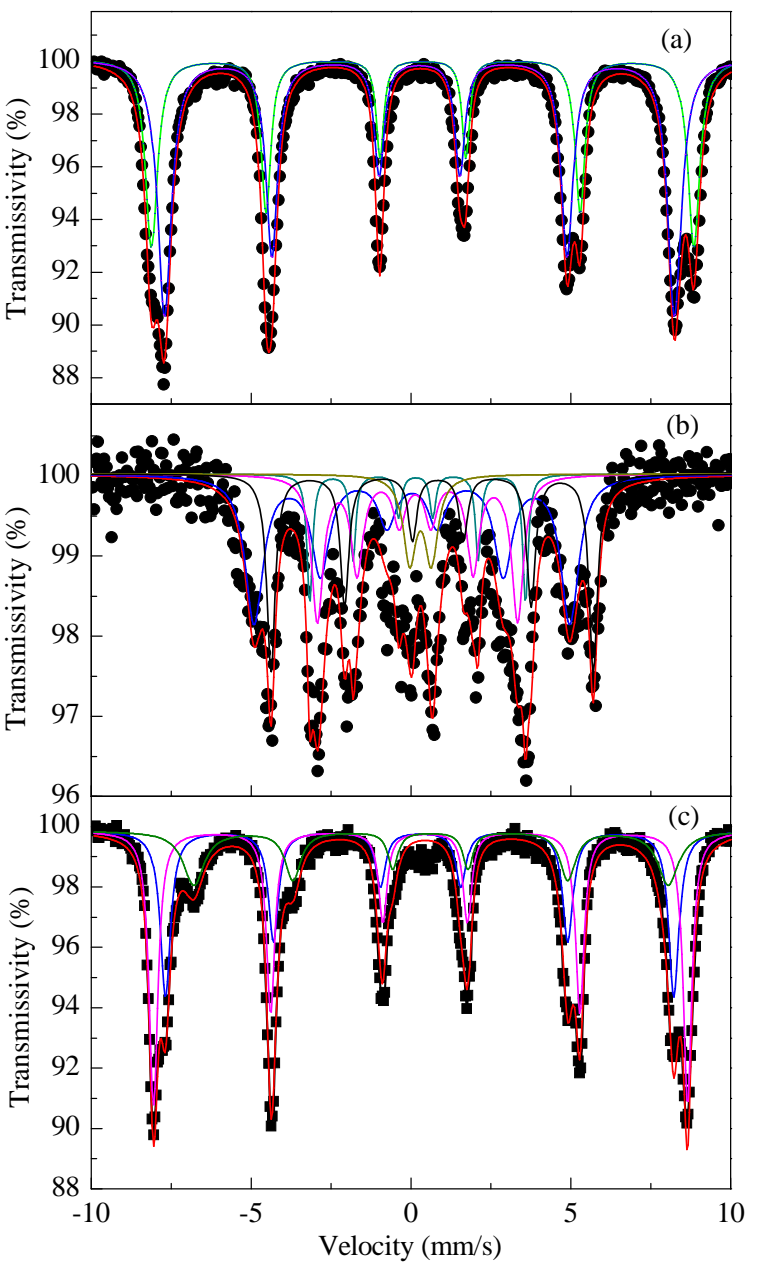

Fig. 5. ${ }^{57} \mathrm{Fe}$ Mössbauer spectra of (a) fresh, (b) spent, and (c) regenerated $\mathrm{NiFe}_{2} \mathrm{O}_{4}$ adsorbent.

The Mössbauer spectrum of the spent $\mathrm{NiFe}_{2} \mathrm{O}_{4}$ sample showed three sextets and two doublets. The sextet with the Mössbauer parameters of IS $=0.03 \mathrm{~mm} / \mathrm{s}, \mathrm{QS}=0.03 \mathrm{~mm} / \mathrm{s}$, and $H=30.7 \mathrm{~T}$ was attributed to A-sites in $\mathrm{Fe}_{1-x} \mathrm{~S}$. The other two sextets, which had IS $=0.18 \mathrm{~mm} / \mathrm{s}, H=21.0 \mathrm{~T}$, and $\mathrm{IS}=0.17$ $\mathrm{mm} / \mathrm{s}, H=19.5 \mathrm{~T}$, were attributed to $\mathrm{Fe}$ atoms at nonequivalent lattice sites $\mathrm{B}$ and $\mathrm{C}$ of $\mathrm{Fe}_{1-\mathrm{x}} \mathrm{S}$, respectively. The two doublets,

Table 2

${ }^{57} \mathrm{Fe}$ Mössbauer parameters of $\mathrm{NiFe}_{2} \mathrm{O}_{4}$ samples.

\begin{tabular}{|c|c|c|c|c|c|c|}
\hline Sample & $\begin{array}{c}A \\
(\%) \\
\end{array}$ & $\begin{array}{c}\delta^{\mathrm{a}} \\
(\mathrm{mm} / \mathrm{s})\end{array}$ & $\begin{array}{c}H \\
(\mathrm{~T}) \\
\end{array}$ & $\begin{array}{c}\Delta \\
(\mathrm{mm} / \mathrm{s})\end{array}$ & $\begin{array}{c}2 \Gamma \\
(\mathrm{mm} / \mathrm{s})\end{array}$ & Site $^{b}$ \\
\hline \multirow[t]{2}{*}{ Fresh } & 61.2 & 0.26 & 49.6 & 0.00 & 0.38 & A-site in $\mathrm{NiFe}_{2} \mathrm{O}_{4}$ \\
\hline & 38.8 & 0.37 & 52.7 & -0.01 & 0.29 & $\mathrm{~B}$-site in $\mathrm{NiFe}_{2} \mathrm{O}_{4}$ \\
\hline \multirow[t]{5}{*}{ Spent } & 36.0 & 0.03 & 30.7 & 0.03 & 0.67 & A-site in $\mathrm{Fe}_{1-x} \mathrm{~S}$ \\
\hline & 9.8 & 0.18 & 21.0 & 0.06 & 0.21 & $\mathrm{~B}$-site in $\mathrm{Fe}_{1-x} \mathrm{~S}$ \\
\hline & 23.6 & 0.17 & 19.5 & 0.08 & 0.44 & C-site in $\mathrm{Fe}_{1-x} \mathrm{~S}$ \\
\hline & 7.40 & 0.30 & - & 0.68 & 0.48 & $\mathrm{Fe}^{3+}$ in $\mathrm{Fe}_{2} \mathrm{~S}_{3}$ \\
\hline & 23.2 & 0.75 & - & -0.18 & 0.32 & $\mathrm{Fe}^{2+}$ in $\mathrm{NiFeS}$ \\
\hline \multirow[t]{3}{*}{ Regenerated } & 33.0 & 0.29 & 49.5 & -0.03 & 0.39 & $\mathrm{~A}$-site in $\mathrm{NiFe}_{2} \mathrm{O}_{4}$ \\
\hline & 45.3 & 0.37 & 51.9 & -0.14 & 0.32 & B-site in $\mathrm{NiFe}_{2} \mathrm{O}_{4}$ \\
\hline & 21.7 & 0.62 & 46.1 & 0.02 & 0.38 & $\alpha-\mathrm{Fe}_{2} \mathrm{O}_{3}$ \\
\hline
\end{tabular}

a Relative to $\alpha$-Fe at room temperature.

${ }^{\mathrm{b}}$ Site identification considered to be the most probable case. 
which had IS $=0.30 \mathrm{~mm} / \mathrm{s}, \mathrm{QS}=0.68 \mathrm{~mm} / \mathrm{s}$ and $\mathrm{IS}=0.75 \mathrm{~mm} / \mathrm{s}$, $\mathrm{QS}=-0.18 \mathrm{~mm} / \mathrm{s}$, were attributed to $\mathrm{Fe}^{3+}$ in $\mathrm{Fe}_{2} \mathrm{~S}_{3}$ and $\mathrm{Fe}^{2+}$ in $\mathrm{NiFeS}$ violarite, respectively [22,23]. According to the above analysis, the spinel $\mathrm{NiFe}_{2} \mathrm{O}_{4}$ adsorbent was almost completely transformed into iron sulfides during the 40-h ADS process. In the dynamic balance of ADS, iron sulfide was reduced by the $\mathrm{H}_{2}$ to form non-stoichiometric $\mathrm{Fe}_{1-\mathrm{x}} \mathrm{S}$ phase. Additionally, nickel ferrites have excellent reaction ADS performance, which may be attributed to Ni functioning as a hydrodesulfurization site [6].

The spent $\mathrm{NiFe}_{2} \mathrm{O}_{4}$ adsorbent was regenerated at $500{ }^{\circ} \mathrm{C}$ for $3 \mathrm{~h}$ in air. The Mössbauer spectrum of regenerated $\mathrm{NiFe}_{2} \mathrm{O}_{4}$ showed three sextets. The two sextets having the Mössbauer parameters of IS $=0.29 \mathrm{~mm} / \mathrm{s}, H=49.5 \mathrm{~T}$ and IS $=0.37 \mathrm{~mm} / \mathrm{s}, \mathrm{H}$ $=51.9 \mathrm{~T}$ were attributed to the $\mathrm{Fe}^{3+}$ ions distributed between the A- and B-sites of $\mathrm{NiFe}_{2} \mathrm{O}_{4}$, respectively. The other sextet was attributed to $\alpha-\mathrm{Fe}_{2} \mathrm{O}_{3}$. Comparison of the Mössbauer spectra of fresh $\mathrm{NiFe}_{2} \mathrm{O}_{4}$ and regenerated $\mathrm{NiFe}_{2} \mathrm{O}_{4}$ indicates that the nickel ferrite adsorbent was also successfully regenerated.

As shown in Fig. 6 and Table 3, the Mössbauer spectrum of fresh $\mathrm{ZnFe}_{2} \mathrm{O}_{4}$ adsorbent showed a doublet with $\mathrm{IS}=0.35$ $\mathrm{mm} / \mathrm{s}, \mathrm{QS}=0.40 \mathrm{~mm} / \mathrm{s}$, which corresponded to $\mathrm{Fe}^{3+}$ ions occupying octahedral sites in the normal spinel phase $\mathrm{ZnFe}_{2} \mathrm{O}_{4}$. The

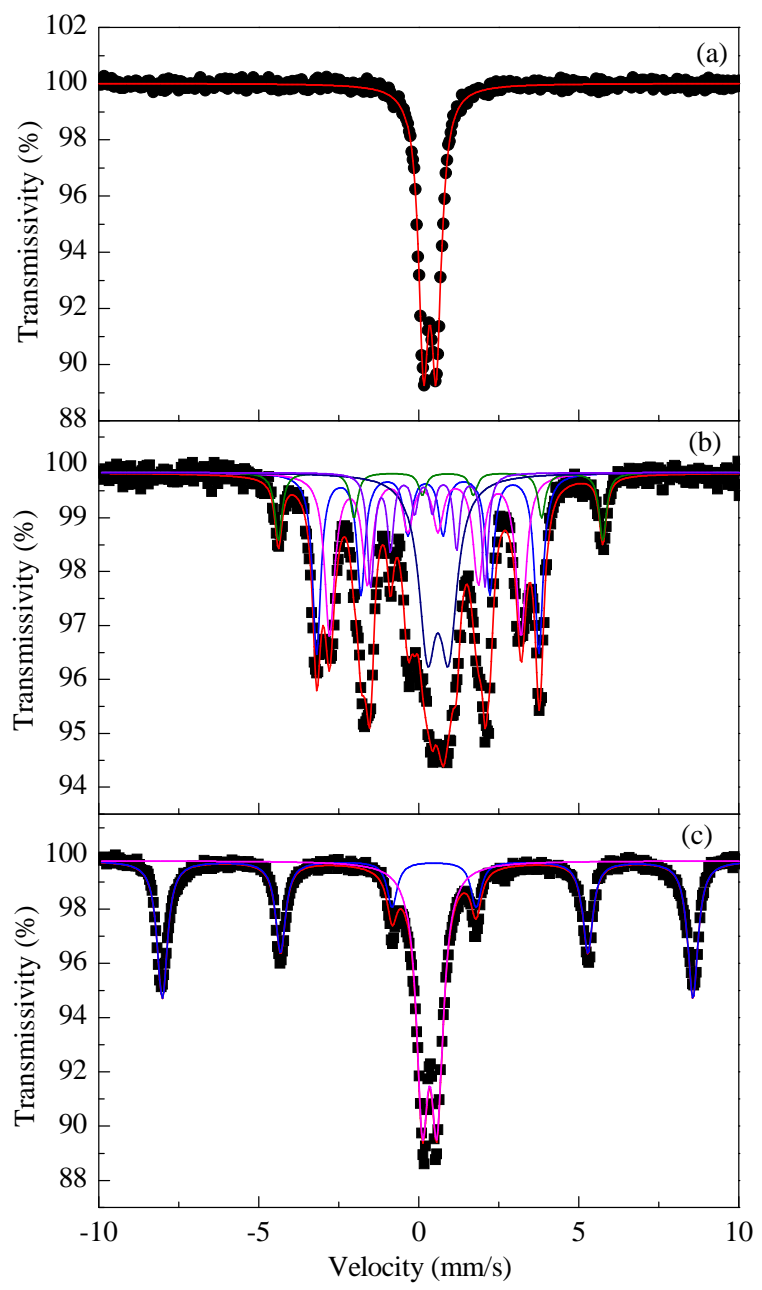

Fig. 6. ${ }^{57} \mathrm{Fe}$ Mössbauer spectra of (a) fresh, (b) spent, and (c) regenerated $\mathrm{ZnFe}_{2} \mathrm{O}_{4}$ adsorbent.
Table 3

${ }^{57} \mathrm{Fe}$ Mössbauer parameters of $\mathrm{ZnFe}_{2} \mathrm{O}_{4}$ samples.

\begin{tabular}{|c|c|c|c|c|c|c|}
\hline Sample & $\begin{array}{c}A \\
(\%) \\
\end{array}$ & $\begin{array}{c}\delta^{\mathrm{a}} \\
(\mathrm{mm} / \mathrm{s})\end{array}$ & $\begin{array}{c}H \\
(\mathrm{~T}) \\
\end{array}$ & $\begin{array}{c}\Delta \\
(\mathrm{mm} / \mathrm{s}) \\
\end{array}$ & $\begin{array}{c}2 \Gamma \\
(\mathrm{mm} / \mathrm{s})\end{array}$ & Site $^{b}$ \\
\hline Fresh & 100 & 0.35 & - & 0.40 & 0.37 & $\mathrm{Fe}^{3+}[\mathrm{O}]$ \\
\hline \multirow[t]{5}{*}{ Spent } & 26.2 & 0.25 & 21.5 & 0.08 & 0.32 & B-site in $\mathrm{Fe}_{1-x} \mathrm{~S}$ \\
\hline & 28.4 & 0.17 & 18.5 & 0.08 & 0.38 & $\mathrm{C}$-site in $\mathrm{Fe}_{1-x} \mathrm{~S}$ \\
\hline & 8.6 & 0.80 & 31.4 & -0.23 & 0.28 & A-site in $\mathrm{Fe}_{1-x} \mathrm{~S}$ \\
\hline & 24.3 & 0.60 & - & 0.65 & 0.65 & $\mathrm{Fe}^{2+}$ in FeZnS \\
\hline & 12.5 & 0.22 & 11.0 & 0.13 & 0.24 & D-site in $\mathrm{Fe}_{1-x} \mathrm{~S}$ \\
\hline \multirow[t]{2}{*}{ Regenerated } & 50.2 & 0.38 & 51.5 & -0.21 & 0.38 & $\alpha-\mathrm{Fe}_{2} \mathrm{O}_{3}$ \\
\hline & 49.8 & 0.34 & & 0.46 & 0.45 & $\mathrm{Fe}^{3+}[0]$ \\
\hline
\end{tabular}

a Relative to $\alpha$-Fe at room temperature.

${ }^{\mathrm{b}}$ Site identification considered to be the most probable case.

structure of the $\mathrm{ZnFe}_{2} \mathrm{O}_{4}$ also changed significantly during the ADS process. The appearance of one doublet and four sextets for spent $\mathrm{ZnFe}_{2} \mathrm{O}_{4}$ may be reasonably assigned to $\mathrm{FeZnS}$ sphalerite and $\mathrm{Fe}_{1-x} \mathrm{~S}$, respectively. There were four nonequivalent iron sites, A, B, C, and D, in the $\mathrm{Fe}_{1-\mathrm{x}} \mathrm{S}$. Under the reducing atmosphere well as the presence of thiophene, the zinc ferrite adsorbent was unstable and readily decomposed into the single oxides $\mathrm{ZnO}$ and $\mathrm{Fe}_{2} \mathrm{O}_{3}$. The ferric oxide was further reduced to metallic iron, which led to the formation of a $\mathrm{Fe}_{1-x} \mathrm{~S}$ structure mixed with sphalerite during the sulfidation process. However, when the sulfided adsorbent was regenerated at $500{ }^{\circ} \mathrm{C}$ for $3 \mathrm{~h}$ in air, its Mössbauer spectrum (Fig. 6(c)) showed a well-defined doublet and a sextet. The Mössbauer parameters shown in Table 3 enabled these sites to be assigned to the presence of $\mathrm{ZnFe}_{2} \mathrm{O}_{4}$ and $\alpha-\mathrm{Fe}_{2} \mathrm{O}_{3}$. Consequently, these Mössbauer results indicate that the regeneration process was effective in eliminating all traces of iron sulfides, although the regenerated adsorbent was incompletely converted to the spinel phase owing to apparent diffusional limitations in the solid-state reaction [8].

\section{Conclusions}

Nanocrystalline $\mathrm{AFe}_{2} \mathrm{O}_{4}$ ferrite adsorbents $(\mathrm{A}=\mathrm{Mg}, \mathrm{Zn}, \mathrm{Ni}$, Co, and CuZn) were successfully synthesized from stoichiometric metal nitrate and urea mixtures using a microwave assisted combustion method. The as-prepared $\mathrm{AFe}_{2} \mathrm{O}_{4}$ were effective adsorbents for the reactive ADS of model gasoline. The ADS reactivity over the ferrites was found to have the following order: $\mathrm{MgFe}_{2} \mathrm{O}_{4}>\mathrm{NiFe}_{2} \mathrm{O}_{4}>\mathrm{CuZnFe}_{2} \mathrm{O}_{4}>\mathrm{ZnFe}_{2} \mathrm{O}_{4}>\mathrm{CoFe}_{2} \mathrm{O}_{4}$. This effect is explained by the fact that the low degree of alloying of $\mathrm{Mg}-\mathrm{Fe}$ and the doped $\mathrm{Mg}$ increased the interaction between Fe and S compounds, leading to a significant improvement in the desulfurization capability of the adsorbent. Additionally, $\mathrm{Mg}$ is a typical basic element which can dramatically promote the decomposition of thiophene. XRD and Mössbauer spectroscopy were used to characterize the fresh, regenerated and sulfided adsorbents in detail. The obtained results indicated a change in oxidation state of the adsorbents. During the adsorption process, the ferrites were partially sulfided to the monometallic and/or bimetallic sulfides. However, the ferrite adsorbents were found to be successfully regenerated under oxidizing conditions. 


\title{
Graphical Abstract
}

Chin. J. Catal., 2016, 37: 727-734 doi: 10.1016/S1872-2067(15)61068-3

\section{Mössbauer spectroscopic characterization of ferrites as adsorbents for reactive adsorption desulfurization}

Xiao Chen, Kaixin Zhu, M. A. Ahmed, Junhu Wang*, Changhai Liang*

Dalian University of Technology, China; Dalian Institute of Chemical Physics, Chinese Academy of Sciences, China;

University of Chinese Academy of Sciences, China; Al Azhar University, Egypt

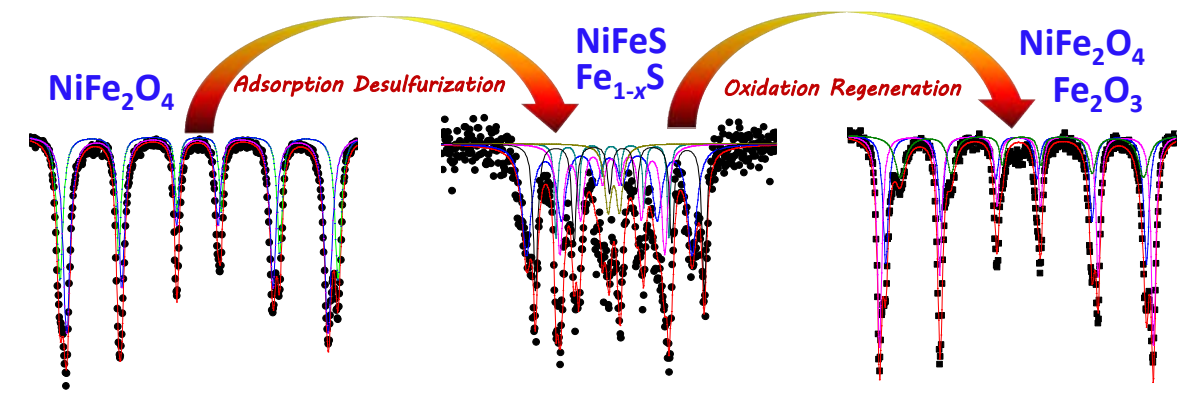

Ferrite adsorbents can be synthesized using a microwave assisted combustion method, yielding a high desulfurization capability. Mössbauer spectroscopy was used to characterize the ferrites. The adsorbents were successfully regenerated under oxidizing conditions.

\section{References}

[1] R. T. Yang, A. J. Hernández-Maldonado, F. H. Yang, Science, 2003, 301, 79-81.

[2] C. S. Song, Catal. Today, 2003, 86, 211-263.

[3] E. Ito, J. A. R. Van Veen, Catal. Today, 2006, 116, 446-460.

[4] K. Tawara, T. Nishimura, H. Iwanami, T. Nishimoto, T. Hasuike, Ind. Eng. Chem. Res., 2001, 40, 2367-2370.

[5] J. C. Zhang, Y. Q. Liu, S. Tian, Y. M. Chai, C. G. Liu, J. Nat. Gas Chem., 2010, 19, 327-332.

[6] J. X. Fan, G. Wang, Y. Sun, C. M. Xu, H. J. Zhou, G. L. Zhou, J. S. Gao, Ind. Eng. Chem. Res., 2010, 49, 8450-8460.

[7] R. Gupta, S. K. Gangwal, S. C. Jain, Energy Fuels, 1992, 6, 21-27.

[8] M. A. Ahmed, L. Alonso, J. M. Palacios, C. Cilleruelo, J. C. Abanades, Solid State Ionics, 2000, 138, 51-62.

[9] M. A. Ahmed, E. García, L. Alonso, J. M. Palacios, Appl. Surf. Sci., 2000, 156, 115-124.

[10] M. H. Mahmoud, A. M. Elshahawy, S. A. Makhlouf, H. H. Hemdeh, J. Magn. Magn. Mater., 2013, 343, 21-26.

[11] A. Manikandan, J. J. Vijaya, L. J. Kennedy, M. Bououdina, J. Mol. Struct., 2013, 1035, 332-340.
[12] Y. L. Zhang, Y. X. Yang, H. X. Han, M. Yang, L. Wang, Y. N. Zhang, Z. X. Jiang, C. Li, Appl. Catal. B, 2012, 119-120, 13-19.

[13] Z. K. Heiba, M. B. Mohamed, H. H. Hamdeh, M. A. Ahmed, J. Alloys Compd., 2015, 618, 755-760.

[14] X. Meng, H. Huang, L. Shi, Ind. Eng. Chem. Res., 2013, 52, 6092-6100.

[15] J. Dvorak, T. Jirsak, J. A. Rodriguez, Surf. Sci., 2001, 479, 155-168.

[16] L. J. Liu, H. J. Liu, M. Q. Cui, Y. F. Hu, J. Wang, Fuel, 2013, 112, 687-694.

[17] I. V. Babich, J. A. Moulijn, Fuel, 2003, 82, 607-631.

[18] F. Li, J. J. Liu, D. G. Evans, X. Duan, Chem. Mater., 2004, 16, 1597-1602.

[19] K. Gandotra, B. S. Randhawa, Hyperfine Interact., 2008, 185, 139-143.

[20] R. C. Sharma, Y. A. Chang, Met. Trans. B, 1979, 10, 103-108.

[21] C. Solís, S. Somacescu, E. Palafox, M. Balaguer, J. M. Serra, J. Phys. Chem. C, 2014, 118, 24266-24273.

[22] I. S. Lyubutin, C. R. Lin, S. Z. Lu, Y. J. Siao, Y. V. Korzhetskiy, T. V. Dmitrieva, Y. L. Dubinskaya, V. S. Pokatilov, A. O. Konovalova, J. Nanopart. Res., 2011, 13, 5507-5517.

[23] J. Cuda, T. Kohout, J. Tucek, J. Filip, O. Malina, M. Krizek, R. Zboril, AIP Conf. Proc., 2014, 1622, 8-11.

\section{铁氧体吸附剂的穆斯堡尔谱解析及其反应吸附脱硫性能}

\author{
陈 霄 ${ }^{\mathrm{a}}$, 朱凯新 ${ }^{\mathrm{b}, \mathrm{c}}$, M. A. Ahmed ${ }^{\mathrm{d}}$, 王军虎 ${ }^{\mathrm{b}, *}$, 梁长海, ${ }^{\mathrm{a}, \#}$ \\ ${ }^{\mathrm{a}}$ 大连理工大学化工学院先进材料与催化工程实验室, 辽宁大连 116012 \\ ${ }^{b}$ 中国科学院大连化学物理研究所穆斯堡尔数据中心, 辽宁大连 116023 \\ c中国科学院大学, 北京 100049 \\ d艾资哈尔大学理学院物理系, 开罗, 埃及
}

摘要: 运输燃料中的含硫化合物依然是空气污染的主要源头. 随着人们环保意识日益增强, 世界各国对燃料油标准特别是 硫含量提出了越来越严格的要求. 为了应对燃料油的无硫化趋势, 探索新型脱硫技术去除油品中的含硫化合物成为研究 热点. 吸附脱硫技术 (ADS) 能够选择性地脱除汽油中的含硫化合物, 而不影响其中的烯烃含量, 从而避免了加氢精制过程 
中烯烃饱和导致的辛烷值降低问题, 成为目前成熟的清洁油品生产技术.

本文采用微波辅助燃烧技术, 将一定化学计量比的金属硝酸盐和尿素混合物快速燃烧反应, 成功合成一系列铁氧体吸 附剂 $\left(\mathrm{MgFe}_{2} \mathrm{O}_{4}, \mathrm{NiFe}_{2} \mathrm{O}_{4}, \mathrm{CuZnFe}_{2} \mathrm{O}_{4}, \mathrm{ZnFe}_{2} \mathrm{O}_{4}, \mathrm{CoFe}_{2} \mathrm{O}_{4}\right)$. 以含有噻吩的正庚烷 (总含硫量 $3000 \mathrm{mg} / \mathrm{L}$ ) 为汽油模型, 在固定 床反应器中 $500{ }^{\circ} \mathrm{C}$ 反应条件下探索了所合成铁氧体吸附剂的吸附脱硫性能. 结果表明, 铁氧体吸附脱硫活性大小为: $\mathrm{MgFe}_{2} \mathrm{O}_{4}>\mathrm{NiFe}_{2} \mathrm{O}_{4}>\mathrm{CuZnFe}_{2} \mathrm{O}_{4}>\mathrm{ZnFe}_{2} \mathrm{O}_{4}>\mathrm{CoFe}_{2} \mathrm{O}_{4}$. 其中 $\mathrm{MgFe}_{2} \mathrm{O}_{4}$ 较其他铁氧体具有更高的吸附脱硫性能. 这是由于 $\mathrm{Mg}-\mathrm{Fe}$ 合金化程度低, 而且掺杂的 $\mathrm{Mg}$ 降低了 $\mathrm{Fe}$ 与 $\mathrm{S}$ 之间的相互作用, 从而显著提高了吸附脱硫性能. 此外, Mg 作为一 种典型的碱金属可在一定程度上显著促进噻吩分解.

$\mathrm{X}$ 射线衍射和穆斯堡尔谱作为敏感的结构和组成检测手段, 广泛用于解析铁氧体吸附剂在吸附脱硫过程中的结构和 相态变化. 通过穆斯堡尔谱成功解析了铁氧体中 Fe 的存在形式及其化合态. 对新鲜铁氧体吸附剂、吸附脱硫后的吸附剂 以及氧化再生的吸附剂进行监测对比, 发现在吸附过程中铁氧体被部分硫化成 $\mathrm{Fe}_{1-\mathrm{x}} \mathrm{S}$ 和双金属硫化物. 在空气中经高温 $\left(500{ }^{\circ} \mathrm{C}\right)$ 处理可成功实现铁氧体吸附剂再生. 本文通过对铁氧体吸附剂的结构解析和性能测试, 为新型吸附脱硫剂开发提 供了理论依据.

关键词: 铁氧体; 吸附脱硫; 穆斯堡尔谱; 再生

收稿日期: 2016-01-13. 接受日期: 2016-02-21. 出版日期: 2016-05-05.

*通讯联系人. 电话: (0411)84379159; 传真: (0411)84685940; 电子信箱: wangjh@dicp.ac.cn

\#通讯联系人. 电话: (0411)84986353; 传真: (0411)84986353; 电子信箱: changhai@dlut.edu.cn

基金来源：国家自然科学基金 (21373038, 21403026, 21476232); 中国博士后基金 (2015T80255, 2014M551068); 中-埃科技交流项 目 (21311140474).

本文的英文电子版由Elsevier出版社在ScienceDirect上出版(http://www.sciencedirect.com/science/journal/18722067). 